\begin{tabular}{|c|c|c|c|}
\hline $\begin{array}{c}\text { RESEARCH } \\
\text { ARTICLE }\end{array}$ & $\begin{array}{r}\text { ADVANCE RESEAF } \\
\text { Volume } 8 \mid \mathbf{I}\end{array}$ & $\begin{array}{l}\text { OCIAL SCIENCE } \\
1-6418\end{array}$ & \\
\hline $0=$ & DOI: $10.15740 / H A S / A R J S S / 8.1 / 1-8$ & Visit us : www.researchjournal.co.in & \\
\hline
\end{tabular}

\title{
An ergonomic evaluation of grain picking activity of farm
} women

P. Parimalam* and J. Meenakshi ${ }^{1}$

Department of Family Resource Management, Home Science College and Research Institute (TNAU), MADURAI (T.N.) INDIA ${ }^{1}$ AICRP of Home Science, Home Science College and Research Institute (TNAU), MADURAI (T.N.) INDIA

(Email: parimalamkannan@hotmail.com; meenakshiganesh81@gmail.com)

\section{ARTICLE INFO :}

Received

Revised

: 30.01 .2017

Accepted

01.04.2017

KEY WORDS :

Ergonomics, Grain picker,

Physiology, Conventional method

HOW TO CITE THIS ARTICLE :

Parimalam, P. and Meenakshi, J. (2017).

An ergonomic evaluation of grain picking activity of farm women. Adv. Res. J. Soc.

Sci., 8 (1) : 1-8, DOI: 10.15740/HAS/

ARJSS/8.1/1-8.

*Author for correspondence

\begin{abstract}
A study on an ergonomic evaluation of the grain picking activity of women using conventional and improved grain picker was conducted in Madurai district of Tamil Nadu. Twenty women workers were made to perform grain picking activity by conventional and improved method. Data on time and work study, physiological parameters, hand grip strength and musculo-skeletal disorder of the women were collected. The results revealed that the improved method of grain picking activity showed high picking efficiency (66.86\%), minimum reduction in grip strength of right hand (17.52\%) and reduced physiological cost of work (19) when compared with conventional method of grain picking.
\end{abstract}

